\title{
LEGAL PRINCIPLES OF REGULATION THE ACTS OF UNLAWFUL INTERFERENCE IN CIVIL AVIATION ACTIVITIES
}

\author{
S.I. KHOMYACHENKO, Candidate of Juridical Sciences, Docent, \\ National University of Life and Environmental Sciences of Ukraine, \\ E-mail: arturmark@ukr.net
}

\begin{abstract}
Summary. The article examines the national legislation of Ukraine. international legal acts, according to which the rules of state regulation of combating acts of unlawful interference with the activity of civil aviation are introduced. It has been found that a sufficiently strong basis was created in the field of aviation law for the further creation and improvement of legal and technical norms regulating the issue of unlawful interference in the activities of civil aviation and ensuring aviation security. However, without the introduction of international legal standards in the field of aviation security and their implementation in the domestic flight safety system, it is almost impossible to carry out and arrange air freight.
\end{abstract}

Keywords: the instances of unlawful interference in operation of civil aviation, aerospace, aviation security, international agreements, civil aviation

\section{Introduction.}

After gaining independence as well as declaring course towards European integration, Ukraine has started actively cooperating with the countries of United Europe in the aerospace industry. Besides, dynamic development of civil aviation and active use of global networks of international air lines requires constant improvement of the legal mechanisms that ensure its proper operation. As for now, Ukraine has broad international obligations under
39 international treaties following international aviation law (including 28 under the aegis of ICAO, 1 under the aegis of ECCA and 7 under the aegis of EUROCONTROL), 70 bilateral intergovernmental air services agreements, the agreement between Ukraine and the EU on certain aspects of air services (the «horizontal agreement») and other international treaties of Ukraine, including the Annex on aviation transport to GATT/WTO, in the framework of the development of regional cooperation within the European region and the 
countries of the Black Sea-Caucasus region. There have been known numerous cases throughout history when societies try to protect themselves from unwanted acts that destroy established way of life by developing certain levels of security (Bryhinets, 2019: 8). In this regard, there has emerged a need to study relevant problems of Ukraine's air and space law, which should be considered in the context of the dynamics of civil relations in the field of civil aviation and the use of outer space, as well as our country's integration into the European community, taking into account the course of sustainable development declared by the international community.

\section{Analysis of recent researches and publications.}

Often, some individuals are tempted to use such high-tech and scientifically valuable inventions as aircrafts inappropriately. Considering that the legal assessment of this negative phenomenon was later enshrined in international legal acts and national legislation as so-called «the struggle against the acts of unlawful interference with the civil aviation activities». Thus, combating acts of unlawful interference with civil aviation is among the most important aspects concerning aviation security today. The destruction of the Ukrainian aircraft «Boeing 737800 UR-PSR» operated by Ukrainian International Airlines on January 8, 2020 in the airspace of the Islamic Republic of Iran has became the second case in the history of independent Ukraine of an act of unlawful interference and once again confirmed the vulnerability of civil aviation to criminal offenses. It should be noted that the problem of legal regulation of the struggle against the acts of unlawful interference with civil aviation activ- ities is not new. It has been the subject of research for many scientists. In particular, directly or indirectly, the following issues were addressed by A. Vereshchagin, E. Eryashov, Y. Maleev, M. Volkov, R. Gerasimov, A. Liakhov, A. Movchan, V. Bordunov, O. Kotov, A. Kislov, V. Ryzhy, V. Chernov, A. Filippov and other scientists. But despite the fact that the problem has been actively researched in the current socio-economic and political context, it has been becoming increasingly relevant again, thus, needs more attention from scientists.

The purpose is to study the issues of legal regulation of combating acts of unlawful interference in civil aviation activities. Special attention is devoted to the need of interaction of the legislation of Ukraine with the relevant norms of international law.

\section{Results.}

An act of unlawful interference with aviation is a deliberate criminal act related to the encroachment on the normal and safe operation of aviation and aviation objects, resulting in accidents with people, property damage, seizure or theft of aircraft, or creating the situation for such consequences (Filippov, 2009: 68 ). The preamble norms to the Convention on International Civil Aviation (1944) contain the provisions stating that abuse of international civil aviation may pose a threat to overall security as well as state-members agree to certain principles and measures for the safe and ordered development when signing this Convention («Convention on International Civil Aviation»). Although indicated international agreement does not directly regulate the relations between the aviation authorities of the signatory states on combating acts of unlawful in- 
terference with civil aviation activities, but its preamble lays the foundation, the legal basis for States' activities through competent authorities for cooperation on the international level and interaction between competent authorities within the state on this issue.

Of course, the rules of the convention create rights and obligations for the states, though, their official aviation authorities, legal and natural persons using the air space by means of aircraft are not directly subject to the rules of international law. In order to ensure the effective implementation of the Convention at the domestic level, Ukraine has implemented it into national law through accession and thus since September 1992 became a full member of the international aviation community.

After the adoption of the new Air Code of Ukraine (hereinafter referred to as AC) in 2011, the activity of airspace users of Ukraine became mainly regulated in order to satisfy the interests of Ukraine and its citizens as well as ensure aviation safety (Air Code of Ukraine). According to paragraph 20 of Art. $1 \mathrm{AC}$, Aviation Security is a state of the civil aviation industry at which the risk of causing damage to people or property is reduced to an acceptable level as a result of the continuous process of determining and managing the level of danger, maintaining it at this level or lowering it futher in the fields of flight safety, aviation security, environmental protection, economic security and information security. In the literature, civil aviation security is regarded as «a complex process that involves the safety of flights, the protection of civil aviation against acts of unlawful interference (aviation security), and the protection of the environment from harmful effects by aviation (environmental safety)» («Legal regulation of the transport sector...», 2006: 312).
Besides, the second part of Art. 10 $\mathrm{AC}$ states that in order to ensure the safety of civil aviation the competent authority for civil aviation implements a set of measures aimed at preventing the occurrence of aviation events through:

1) establishment of aviation security criteria;

2) establishment of the required level of aviation security;

3) analysis and determination of the existing level of aviation security;

4) carrying out planned and unscheduled inspections, inspection of subjects and objects of aviation activity;

5) setting deadlines and exercising control over the conduct of corrective actions by aviation entities;

6) prohibition, cancellation, temporary suspension or change of implementation of any type of flights and aviation activity in case of detection of threat to aviation safety or non-compliance with established standards and aviation rules of Ukraine;

7) cancellation, temporary suspension of certificates, licenses, permits, restrictions on the rights granted by these documents, cancellation of the approval of candidates in accordance with part ten of this Article;

8) imposing fines and taking other measures to ensure aviation security.

The section XI of the AC of Ukraine is devoted to the protection of civil aviation against acts of unlawful interference. The organization of aviation security is determined in the part 2 of Art. 85 of the AC of Ukraine, under which «protection of civil aviation against acts of unlawful interference is ensured by implementing a set of organizational and practical measures, as well as by attracting human and material resources in accordance with the State program of aviation security of civil aviation and normative legal acts on 
aviation security». The relevant program was approved by the Law of Ukraine «On the State Program of Civil Aviation Safety of Civil Aviation» of March 21, 2017 («About the State Aviation Security Program...»).

The State Aviation Security Program for Civil Aviation (hereinafter referred to as the Program) is designed in accordance with the standards and recommended practice of the Convention on International Civil Aviation (Chicago, December $7,1944)$ and the obligations arising from Ukraine being part of the Convention on crimes and certain other acts, carried out on the aircrafts (Tokyo, September 14, 1963), the Protocol to Combat Illicit Violence at Airports Serving International Civil Aviation (Montreal, February 24, 1988), the Plastic Labeling Convention explosives for the purpose of their detection (Montreal, March 1, 1991), Annex 17 to the Convention on International Civil Aviation «Security Protection of International Civil Aviation from Unlawful Intervention», the Aviation Safety Guide (Doc 8973), as well as other international acts and acts of Ukrainian legislation. The State Aviation Security Program for Civil Aviation will ensure the implementation of standards and recommended practices of international organizations (ICAO, ECACA, Eurocontrol).

It should be noted that as for the international legal and foreign economic activity of civil aviation, the Ukrainian authorities during the Soviet and independence years using many various ways have implemented multilateral universal and regional international agreements on aviation security and protection of civil aviation against acts of unlawful interference in the national legislation. Among which are the following: European Convention for the Suppression of Terrorism of 27.01.1977 (The Convention was ratified by the Law No 2990-III of 17.01.2002); the Convention for the Suppression of Unlawful Seizure of Aircraft, signed at Hague on December 16, 1970; Convention for the Suppression of Unlawful Acts Against the Safety of Civil Aviation, signed at Montreal on 23 September 1971; Agreement on Civil Aviation and Use of Airspace of 25.12.1991; Agreement on cooperation on ensuring protection of civil aviation against acts of unlawful interference dated 26 May 1995; International Convention on Cooperation in the Field of Air Navigation «EUROCONTROL» of 13.12.1960; European Convention on Extradition of Offenders, of 13.12.1957.

However, only some of them will be disclosed further: the Tokyo Convention on Crimes and Some Other Actions Taken aboard an Aircraft 1963:

- applies to acts that threaten flight safety;

- gives the aircraft commander the right to take reasonable steps, including restrictive measures, against any person if he/she has reason to believe that such person has committed or is about to carry out such an act, in case if it is necessary to ensure the safety of the aircraft;

- obliges Contracting States to detain criminals and restore control of a lawful commander over an aircraft.

The Hague Convention on the Suppression of Unlawful Seizure of Aircraft, 1970:

- qualifies as a criminal act when any person on the aircraft during the flight «unlawfully, by force, or through any other form of intimidation, seizes or takes control of the aircraft; or attempting to do so»;

- obliges the parties of the Convention to take «severe measures» for the seizure of the aircraft; 
- oblige the parties holding the criminals in custody to extradite them or to transfer those case to their competent authorities for criminal purposes;

- oblige the parties to assist each other in the procedural steps provided in the Convention.

Montreal Convention for the Suppression of Unlawful Acts Against the Safety of Civil Aviation of 1971:

- qualifies as offences the acts of unlawful interference with civil aviation activities;

- obliges the parties of the Convention to take «severe measures» for such crimes;

- obliges the parties holding the criminals in custody to extradite them or to transfer those case to their competent authorities for criminal purposes.

Protocol for the Suppression of Unlawful Acts of Violence at the airports that serve International Civil Aviation of 1988, supplementing the 1971 Montreal Convention:

- extends the provisions of the Montreal Convention with a purpose of expanding its scope at terrorist acts carried out at the airports that serve international civil aviation.

These international documents constitute a system of treaties on the unlawful interference with civil aviation, which is an integral part of international aviation law. Using them as a base during 1960-80 of the last century most states have adopted relevant laws in national legal systems. However, despite that, acts of unlawful interference with civil aviation activities have not been stopped yet. In our opinion, the reason for that is not only certain shortcomings of the abovementioned conventions, which are related to the imperfect mechanisms of international struggle against such offenses, but also improper qualification of such offenses, the resolution of which should facilitate their successful counteraction.

Besides, at the ICAO level, certain aviation states have signed (not yet ratified) the documents that are aimed at securing a new international legal order concerning the struggle with the acts of unlawful interference, namely: the Beijing Convention of 2010, the Beijing Protocol of September 10, 2010, the Montreal Protocol of April 4, 2014. Furthermore, the effectiveness of the struggle against the acts of unlawful interference depends on the application of preventive measures, both legal and administrative. The current conventions concerning this area contain mainly declarative provisions for the introduction of preventive measures by the States. As for now, the struggle against the acts of unlawful interference with civil aviation is closely linked to international counter-terrorism activities. The phenomenon that was first named as «air terrorism» by the media has indeed become one of the most effective «tools» of modern terrorism. The terrorist threat to international civil aviation is a real danger that requires appropriate active response not only by the International Civil Aviation Organization (ICAO). Some states may consider that the threat of air terrorism does not concern them. An analysis of this threat shows that due to the network nature of civil aviation, this view is erroneous. The threat is common to all, and so all states must be concerned about civil aviation safety.

\section{Conclusions and prospects.}

Summarizing all of the above, it should be emphasized that considering globalization of the basic processes of social and economic life, the state regu- 
lation of combating acts of unlawful interference with civil aviation is carried out taking into account the existing legal acts of both international and national nature of different legal powers. The Hague and Montreal Conventions have created an international legal framework to combat relevant offenses. Along with establishing international air services, cooperating with the international aviation community, strict adherence to the principle of pacta sunt servand has an important role for Ukraine in combating acts of unlawful interference as well as enhancement of the role of its legal means, among which one of the key places holds the institution of state responsibility for failure to comply with international obligations.

\section{References}

1. Bryhinets, O.O. (2019). A dynamic approach to the study of problems state security.
Law. Human. Environment, 10(1): 6-11, https://doi.org/10.31548/law2019.01.001 (in Ukrainian).

2. Filippov, A.V. (2009). The concept of the act of unlawful interference with aviation in international and domestic law. Scientific works of the National Aviation University. Series: Legal Bulletin «Air and Space Law», 4 (13): 65-68 (in Ukrainian).

3. Convention on International Civil Aviation (Chicago, 1944). Available at: https://zakon.rada.gov.ua/laws/show/995_038 (in Ukrainian).

4. Air Code of Ukraine 19.05.2011 No 3393-VI (2011). The Official Journal of Ukraine, 46, 1881 (in Ukrainian).

5. Legal regulation of the transport sector in the European Union and Ukraine (2006). Edited by V.G., Didika. 2 volume: Volume 1. Kyiv: Nika-Print LLC, 392 (in Ukrainian).

6. About the State Aviation Security Program for Civil Aviation (2017): Law of Ukraine 20.03.2017. Verkhovna Rada of Ukraine, 16, 199 (in Ukrainian).

C.І. Хом'яченко (2020). Правові засади регулювання боротьби з актами незаконного втручання в діяльність цивільної авіачії. Право. Людина. Довкілля, 11(1): 124-129. https://doi.org/10.31548/law2020.01.015.

Анотація. У статті досліджено національне законодавство України. міжнародно-правові акти, відповідно до яких запроваджуються правила державного регулювання боротьби з актами незаконного втручання в діяльність цивільної авіації. Встанвлено, що в срері повітряного права була створена досить потужна основа для подальшого створення і вдосконалення юридико-технічних норм, що регулюють питання незаконного втручання в діяльність цивільної авіації та забезпечення авіаційної безпеки. Проте, без запровадження міжнародно правових стандартів у срері забезпечення авіаційної безпеки та імплементації їх у внутрішньодержавну систему забезпечення безпеки польотів практично неможливо здійснювати і організовувати повітряні перевезення.

Ключові слова: авіакосмічна галузь, безпека авіачії, міжнародні угоди, цивільна авіація 